\title{
Bagaimana Meningkatkan Kinerja Karyawan Perusahaan Logistik? Studi Pada PT. JNE Cabang Kota Malang
}

\author{
Ahmad Nizar Yogatama ${ }^{1}$, Mutiara Erwiningtyas ${ }^{2}$ \\ Institut Teknologi dan Bisnis Asia
}

\begin{abstract}
Along with the increasing demand for domestic logistics, especially in Malang City, the performance of logistics companies is important, especially PT. JNE Malang City Branch. As a service company, the best service to consumers is the main key to employee performance. Employee performance of PT. JNE Malang City Branch can be increased through the provision of appropriate compensation and work motivation. This study aims to determine the relationship between compensation and work motivation on performance at PT. Nugraha Ekakurir (JNE) Malang City Branch. This study used proportional sampling techniques across divisions with a total of 81 employees and was analyzed using multiple linear regression analysis. The results of this study state that the compensation and work motivation of the employees of PT. Malang City Branch JNE has a significant effect on employee performance
\end{abstract}

Keywords: Compensation, Work Motivation, Performance, Logistics

\begin{abstract}
Abstrak
Seiring dengan meningkatnya permintaan logistik dalam negeri khususnya di Kota Malang, maka kinerja perusahaan logistik menjadi penting khususnya PT. JNE Cabang Kota Malang. Sebagai perusahaan jasa, pelayanan terbaik kepada konsumen menjadi kunci utama kinerja karyawan. Kinerja karyawan PT. JNE Cabang Kota Malang dapat ditingkatkan melalui pemberian kompensasi dan motivasi kerja yang tepat. Penelitian ini bertujuan untuk mengetahui hubungan antara kompensasi dan motivasi kerja terhadap kinerja di PT. Jalur Nugraha Ekakurir (JNE) Cabang Kota Malang. Penelitian ini menggunakan teknik pengambilan sampel proporsional di seluruh divisi dengan total 81 karyawan serta dianalisis menggunakan analisis regresi linier berganda. Hasil penelitian ini menyatakan bahwa kompensasi dan motivasi kerja karyawan PT. JNE Cabang Kota Malang berpengaruh signifikan terhadap kinerja karyawan.

Kata kunci: Kompensasi, Motivasi Kerja, Kinerja, Logistik

\begin{tabular}{lcl}
\hline Permalink/DOI & $:$ & http://dx.doi.org/10.32503/jmk.v6i2.1446 \\
Sejarah Artikel & $:$ & $\begin{array}{l}\text { Artikel diterima (10 April 2021); direvisi (25 April 2021); } \\
\text { disetujui (10 Mei 2021) }\end{array}$ \\
Korespondensi & $: \begin{array}{l}\text { Jl. Soekarno Hatta - Rembuksari No. 1A, Kota Malang/ Institut } \\
\text { Teknologi dan Bisnis Asia Malang }\end{array}$ \\
Email & $:$ nizaryogatama@asia.ac.id
\end{tabular}
\end{abstract}




\section{Pendahuluan}

Pada tahun 2018, setiap karyawan PT. Jalur Nugraha Ekakurir (JNE) Cabang Kota Malang memiliki RKK (Rencana Kerja Karyawan) yang terukur dan terarah sesuai dengan deskripsi pekerjaan masing-masing karyawan yang juga diatur pada buku saku peraturan perusahaan dan KPI (Key Performance Indicator) untuk mencapai prestasi kerja. Hal ini penting mengingat semakin berkembangkan transaksi online di Indonesia. Kinerja karyawan menjadi salah satu bagian penting perusahaan untuk mempertahankan dan meningkatkan kinerja perusahaan secara keseluruhan. Sebelum adanya RKK, penilaian terhadap kinerja karyawan dalam rangka meningkatkan performa dari karyawan sulit untuk dilakukan, namun setelah kemunculan dari RKK ini penilaian dapat lebih mudah dilakukan karena lebih terstruktur. Selain itu, kinerja karyawan bagi perusahaan logistik menjadi motor penggerak utama karena bagian dengan persentase terbesar adalah bagian ekspedisi yakni bagian pengantaran barang kepada konsumen.

Pada tahun 2017, PT. Jalur Nugraha Ekakurir (JNE) Cabang Kota Malang memiliki visi untuk membentuk sumber daya manusia yang prima. Hal ini dimulai dengan proses rekrutmen yang tertib administrasi hingga implementasi pelatihan tentang dasar-dasar kepegawaian disertai dengan workflow. Proses yang dilakukan ini, berhasil memberikan outcome pada tahun 2018, yaitu perubahan mindset dan motivasi kerja oleh karyawan. Pada awalnya, selama ini karyawan hanya mengandalkan rutinitas sebagai syarat bahwa seorang karyawan telah bekerja, namun yang berbeda di tahun 2018 ini setiap karyawan memiliki RKK (Rencana Kerja Karyawan) yang terukur dan terarah sesuai dengan deskripsi pekerjaan masing-masing karyawan yang juga diatur pada buku saku peraturan perusahaan dan KPI (Key Performance Indicator) untuk mencapai prestasi kerja.

Untuk mencapai RKK yang sesuai dengan KPI-nya, maka karyawan akan diberikan dua pilihan hal diantaranya yaitu pertama, jika karyawan bisa mencapai RKK yang sudah ditentukan oleh perusahaan, maka karyawan akan mendapatkan kompensasi berupa reward, dan sebaliknya jika karyawan tidak dapat menyelesaikan tugas yang sudah diberikan oleh perusahaan dengan tepat waktu atau tidak mencapai target, maka karyawan tersebut akan mendapatkan punishment dalam bentuk teguran lisan, teguran tertulis, peringatan, pembinaan, pemotongan insentif, sampai dengan Pemutusan Hubungan Kerja (PHK).

PT. Jalur Nugraha Ekakurir (JNE) Cabang Kota Malang pada tahun 2018 faktanya memiliki karyawan tetap sebanyak 438 orang, sehingga saat itu yang menjadi fokus manajemen adalah bagaimana perusahaan bisa memaksimalkan kepuasan kerja karyawan. Maksimalisasi kepuasan ini, dilakukan melalui sistem kompensasi yang baik, diikuti dengan motivasi kerja yang cukup seperti melalui insentif. Tujuan akhirnya adalah untuk menghindari penurunan kinerja karyawan karena PT. JNE Cabang Kota Malang bergerak dibidang jasa (Ketkaew et al., 2020; Juvendy \& Hendriati, 2020). Menariknya adalah pemberian kompensasi terhadap karyawan perlu mempertimbangkan regulasi perusahaan seperti, sistem perusahaan untuk penggajian karyawan, kebijakan kompensasi perusahaan lainnya yang didasarkan atas prestasi kerja dengan syarat-syarat yang berlaku (Baker et al., 1988; Nzyoka \& Orwa, 2016). Disatu sisi, kinerja juga bisa ditingkatkan melalui pemberian motivasi (Nizam, 2015; Olusadum \& Anulika, 2018). Pemberian motivasi kerja bisa dilakukan melalui hubungan kerja yang baik antara atasan 
dengan bawahan maupun sesama karyawan (Rodwell et al., 1998; Smolders \& Vanderstraeten, 2013; Nizam, 2015; Olusadum \& Anulika, 2018).

Fakta dilapangan menunjukkan bahwa masih ada kecenderungan yang terjadi di PT. Jalur Nugraha Ekakurir Cabang Kota Malang yaitu ketidakpuasan karyawan atas pemberian kompensasi berupa upah lembur yang diberikan tidak tepat waktu. Hal ini menciptakan kinerja karyawan tidak maksimal karena adanya kekecewaan dalam pemberian upah lembur yang telah diharapkan sesuai waktu tambahan pekerjaan yang telah mereka kerjakan (Tsai et al., 2016). Kekecewaan karyawan sejatinya dapat diatasi dengan cara memberikan motivasi kerja kepada karyawan oleh pemimpin (Rajhans, 2012; sai et al., 2016; Olusadum \& Anulika, 2018). Seperti halnya yang sudah dilakukan oleh beberapa peneliti sebelumnya, motivasi dilakukan langsung oleh Atasan atau disebut sebagai Branch Manager di PT. JNE Cabang Kota Malang dengan tegas untuk datang ke lapangan dalam memberikan semangat setiap hari kepada para karyawannya, mendengarkan dan memberikan masukan atau jalan keluar untuk kesulitan yang dialami karyawannya dalam pekerjaan.

Sebenarnya banyak cara yang dilakukan perusahaan untuk lebih mengenal para karyawannya seperti adanya kegiatan outbound, gathering, dan lain-lain. Hal ini menandakan bahwa karyawan merasa terpuaskan dengan bentuk-bentuk motivasi yang diberikan atasan, serta secara otomatis akan menciptakan lingkungan kerja yang baik pula bagi perusahaan, memberikan kenyamanan karyawan dalam bekerja, sehingga karyawan dapat bekerja dengan tenang, nyaman dan senang dengan hasil kerja yang maksimal. Namun, terdapat satu hal yang terlupa yakni pemberian motivasi hendaknya disesuaikan dengan bagian dari masing-masing karyawan yang mana sifatnya tidak bisa disamakan. Ada kalanya bentuk motivasi yang diberikan kepada operational inbound tidak sama dengan operational outbound. Sejatinya akan ada banyak hal yang bisa menjadi penyebab terjadinya situasi seperti ini.

Dalam penelitian ini. Peneliti bermaksud untuk mengisi gap penelitian tentang kinerja yang sebelumnya dibahas oleh Mutmainah pada tahun 2017 tentang karakteristik individu, dimana penelitian ini menambahkan dua variabel yakni kompensasi dan motivasi kerja. Dari sisi jumlah responden, penelitian ini juga lebih baik dari penelitian sebelumnya karena menggunakan teknik proportional sampling dimana semua divisi yang ada pada PT. JNE Cabang Kota Malang ikut dianalisis sehingga penelitian ini mampu menunjukkan hasil yang lebih baik dan menyeluruh dibandingkan empiris sebelumnya. Penelitian ini juga memiliki kemampuan memprediksi yang lebih baik terhadap kinerja karyawan PT. JNE Cabang Kota Malang sehingga bisa dijadikan sebagai rujukan dalam pengambilan keputusan terutama di masa pandemi saat ini dimana perusahaan logistik memainkan peran penting dalam aktivitas transaksi ekonomi.

Dalam sebuah organisasi atau perusahaan, kompensasi dan motivasi sangat penting dalam meningkatkan kinerja karyawan (Rajhans, 2012; sai et al., 2016; Olusadum \& Anulika, 2018). Kompensasi bagi karyawan PT. JNE Cabang Kota Malang adalah pemacu seseorang melaksanakan kegiatan untuk mendapatkan hasil terbaik, motivasi kerja disatu sisi juga perlu dibangkitkan agar karyawan PT. JNE Cabang Kota Malang dapat memberikan hasil kerja terbaik, sebaliknya karyawan yang tidak mempunyai motivasi atau semangat yang tinggi dalam melakukan pekerjaannya akan sulit untuk bekerja dengan baik dan cenderung tidak 
bertanggung jawab sekalipun karyawan tersebut memiliki kemampuan operasional yang baik (William, 2010; Rajhans, 2012; sai et al., 2016; Olusadum \& Anulika, 2018). Apabila motivasi kerja karyawan PT. JNE Cabang Kota Malang bisa dibangun, maka mereka dapat memiliki kinerja yang lebih baik di dalam perusahaan.

Jika mengacu pada penelitian Agustin dan Sumantri pada Tahun 2017 yakni penentuan rute pengiriman di penyelenggara jasa logistik (LSP) dengan meninjau kinerja jalan di Kota Malang, telah terjadi kelebihan beban terhadap jumlah kendaraan yang melintasi jalur-jalur yang digunakan oleh perusahaan yang bergerak dibidang jasa logistik, sehingga pengiriman barang berpotensi mengalami keterlambatan (Agustin \& Sumantri, 2017). Melihat ketatnya persaingan dalam bidang jasa pengiriman barang di Indonesia terutama di Kota Malang sekarang ini, penelitian terhadap kinerja karyawan pada perusahaan logistik seperti PT. JNE Cabang Kota Malang menjadi menarik karena adanya pengaruh dari kompensasi dan motivasi kerja di perusahaan tersebut akan berpengaruh terhadap kinerja perusahaan secara keseluruhan nantinya (Agustin \& Sumantri, 2017; Nugroho et al., 2020). Secara sederhana, peneliti sebelumnya menjelaskan bahwa dengan tersedianya beberapa penyedia layanan logistik di Kota Malang, maka rute pengiriman perlu untuk diperhatikan sehingga tidak terjadi penumpukan dijalan, selain itu juga dapat mempercepat waktu perjalanan barang sampai tepat waktu kepada konsumen karena ketika konsumen mendapatkan barang secara tepat waktu, maka ia akan puas dan secara jangka panjang akan bertahan untuk tetap menggunakan jasa dari JNE. Beberapa penelitian ini fokus pada rute pengiriman dan pelanggan atau konsumen, dimana terdapat satu hal yang terlupa yakni fokus pada karyawan yang bertindak sebagai pemain utama dalam rangka memastikan barang dapat diterima dengan baik oleh konsumen sehingga kepuasan konsumen tetap terjaga.

Beberapa peneliti sebelumnya yang fokus pada rute pengiriman dan konsumen menjadikan keterbatasan studi pada bidang sumber daya manusia, oleh karena itu dalam penelitian ini, peneliti lebih dalam untuk membahas tentang pemberdayaan sumber daya manusia dalam hal ini adalah karyawan sehingga tujuan dari penelitian ini adalah untuk mengetahui hubungan antara kompensasi dan motivasi kerja terhadap kinerja di PT. Jalur Nugraha Ekakurir (JNE) Cabang Kota Malang. PT. Jalur Nugraha Ekakurir (JNE) Cabang Malang ini adalah perusahaan logistik terpercaya di kota Malang karena bergerak di bidang jasa, maka karyawan terutama bagian ekspedisi yang dimiliki menjadi salah satu aspek penting dalam keseluruhan proses kinerja perusahaan ini. Program pengembangan dan pelatihan karyawan harus tetap dilakukan di tengah kesibukan pekerjaan yang dibatasi oleh waktu. Kontribusi yang diberikan penelitian ini terhadap pengetahuan baru adalah penggunaan kompensasi dan motivasi yang tepat akan mampu memberikan peningkatan terhadap kinerja lebih baik dibandingkan dengan pemberian kompensasi dan motivasi secara umum tanpa memperhatikan aspek sumber daya manusia dengan lebih baik. 


\section{Metode Penelitian}

Penelitian ini dilaksanakan pada tahun 2019 selama enam (6) bulan yakni Desember 2018 s.d. Mei 2019 melalui wawancara dan kuesioner di PT. JNE Cabang Kota Malang. Penelitian ini menggunakan tiga variabel, diantaranya adalah kompensasi, motivasi kerja dan kinerja karyawan. Untuk melakukan pengukuran terhadap masing-masing variabel tersebut, peneliti menggunakan skala likert 1-5. Terkait dengan parameter untuk setiap variabel, peneliti menggunakan beberapa indikator diantaranya adalah (1) kompensasi menggunakan empat indikator yaitu menarik, legalitas, kompetitif serta adil; (2) motivasi menggunakan tiga indikator yaitu kebutuhan keberadaan, kebutuhan keterkaitan dan kebutuhan pertumbuhan; (3) kinerja menggunakan tiga indikator yaitu kuantitas kerja, kualitas kerja dan ketepatan waktu.

Secara lebih mendetail, dalam penelitian ini kompensasi merupakan balas jasa yang diterima karyawan atas jasa yang mereka sumbangkan pada pekerjaannya (Bangun, 2012). Jika menurut Sutrisno (2013) kompensasi adalah segala sesuatu yang diterima oleh karyawan sebagai balas jasa untuk aktivitas kerja mereka (Sutrisno, 2013). Hal ini kemudian dilengkapi oleh Hasibuan tahun 2016 yang menyatakan bahwa kompensasi adalah semua pendapatan yang berbentuk uang, barang langsung atau tidak langsung yang diterima karyawan sebagai imbalan atas jasa yang diberikan kepada perusahaan (Hasibuan, 2016). Kasmir juga menambahkan tahun 2016 kompensasi merupakan balas jasa yang diberikan perusahaan kepada karyawannya, baik yang bersifat keuangan maupun non keuangan (Kashmir, 2016). Mengacu pada beberapa pendapat ahli maka kompensasi pada penelitian ini adalah segala sesuatu yang diterima karyawan sebagai balas jasa atas pekerjaan yang telah dilakukannya. Dalam penelitian ini menggunakan beberapa indikator untuk mengukur kompensasi, diantaranya adalah (1) menarik, terkait dengan sistem dan ketepatan waktu pemberian kompensasi, tunjangan dan bonus sesuai dengan pekerjaan yang dilaksanakan di PT. JNE Cabang Kota Malang; (2) legalitas, terkait dengan sistem kompensasi yang bertujuan untuk memenuhi peraturan-peraturan legal seperti Upah Minimum Regional (UMR) dan Jaminan Sosial Tenaga Kerja yang diberikan kepada karyawan PT. JNE Cabang Kota Malang; (3) kompetitif, terkait dengan sistem kompensasi yang sebanding dengan perusahaan logistik yang lain dengan bidang pekerjaan yang sama dengan memberikan kenaikan gaji secara berkala; (4) adil, terkait dengan kesesuaian antara penerimaan kompensasi dengan jenis pekerjaan, tanggung jawab pekerjaan dan masa kerja di PT. JNE Cabang Kota Malang.

Motivasi adalah suatu tindakan untuk mempengaruhi orang lain agar berperilaku secara teratur (Bangun, 2012), sedangkan menurut Sutrisno tahun 2013, motivasi adalah suatu faktor yang mendorong seseorang untuk melakukan suatu aktivitas tertentu, oleh karena itu motivasi sering kali diartikan pula sebagai faktor pendorong perilaku seseorang (Sutrisno, 2013). Mengacu pada pendapat beberapa ahli tersebut, maka motivasi kerja pada penelitian ini adalah sesuatu yang dapat menimbulkan semangat seseorang dalam bekerja. Motivasi kerja dalam penelitian ini diukur menggunakan beberapa indikator diantaranya yaitu (1) kebutuhan keberadaan, terkait dengan kebutuhan untuk mempertahankan keberadaan secara fisik maupun psikologis dalam suatu organisasi oleh karyawan PT. JNE Cabang Kota Malang; (2) kebutuhan keterkaitan, terkait dengan kebutuhan untuk 
berinteraksi dengan orang lain yang meliputi kebutuhan sosial dan pengakuan dari lingkungan kerja di PT. JNE Cabang Kota Malang; (3) kebutuhan pertumbuhan, terkait dengan kebutuhan dan keinginan karyawan untuk mengembangkan kemampuan dan keterampilan dalam bekerja di PT. JNE Cabang Kota Malang.

Kinerja karyawan adalah hasil kerja secara kualitas dan kuantitas yang dicapai oleh seseorang karyawan dalam melaksanakan tugasnya sesuai dengan tanggung jawab yang diberikan kepadanya (Sutrisno, 2013). Kinerja merupakan sistem yang digunakan untuk menilai dan mengetahui apakah seorang karyawan telah melaksanakan pekerjaannya secara keseluruhan, atau merupakan perpaduan dari hasil kerja dan kompetensi bagaimana seseorang mencapainya (Sedarmayanti, 2011). Kinerja juga bisa diartikan sebagai suatu hasil yang dicapai oleh pegawai dalam pekerjaannya menurut kriteria tertentu yang berlaku untuk suatu pekerjaan (Robbins, 2008). Mengacu pada beberapa pendapat ahli, kinerja karyawan dalam penelitian ini adalah aksi yang dilakukan karyawan untuk menemukan suatu hasil dalam pekerjaan, bisa diartikan juga sebagai hasil atau nilai dari kemampuan seseorang dalam bekerja. Kinerja karyawan dalam penelitian ini diukur menggunakan beberapa indikator, diantaranya yaitu (1) kuantitas kerja, terkait dengan hasil yang dicapai oleh karyawan dalam jumlah tertentu dengan perbandingan standar ada atau ditetapkan oleh PT. JNE Cabang Kota Malang; (2) kualitas kerja, terkait dengan suatu standar hasil yang berkaitan dengan mutu dari suatu produk yang dihasilkan oleh karyawan dalam hal ini merupakan suatu kemampuan karyawan dalam menyelesaikan pekerjaan secara teknis dengan perbandingan standar yang ditetapkan oleh PT. JNE Cabang Kota Malang; (3) ketepatan waktu, terkait dengan aktivitas yang diselesaikan pada awal waktu yang ditentukan, dilihat dari sudut koordinasi dengan hasil output serta memaksimalkan waktu yang tersedia untuk aktivitas lain, dimana ketepatan waktu diukur dari persepsi karyawan terhadap suatu aktivitas yang disediakan di awal waktu sampai menjadi sebuah output.

Tabel 1. Responden Penelitian

\begin{tabular}{lcc}
\hline \multicolumn{1}{c}{ Divisi } & Karyawan & Sampel \\
\hline Operational Inbound & 220 & 41 \\
\hline Operational Outbound & 95 & 17 \\
\hline Customer Care & 25 & 5 \\
\hline Sales \& Marketing & 42 & 8 \\
\hline Finance \& ACC & 15 & 3 \\
\hline HRD \& Admin & 41 & 7 \\
\hline TOTAL & $\mathbf{4 3 8}$ & $\mathbf{8 1}$ \\
\hline
\end{tabular}

Sumber: diolah peneliti, 2019 
Penelitian ini menggunakan teknik pengambilan sampel proporsional, yaitu jumlah sampel yang diambil dari setiap strata atau divisi yang sebanding, sesuai dengan proporsional ukurannya yang dapat dilihat pada Tabel 1. Responden Penelitian. Dengan menggunakan rumus slovin, maka total responden pada penelitian ini adalah 81 karyawan. Prosedur pengambilan sampel adalah dengan cara undian, alasan menggunakan undian adalah bagi peneliti cukup sederhana dan memungkinkan ketidakadilan dapat dihindari. Untuk teknik analisis data, penelitian ini menggunakan analisis regresi linier berganda.

\section{Hasil dan Pembahasan}

Penelitian ini memiliki instrumen penelitian yang valid dan reliabel berdasarkan uji validitas dan reliabilitas yang dapat dilihat pada Tabel 2 .

Tabel 2. Uji Validitas

\begin{tabular}{|c|c|}
\hline Indikator & r-hitung \\
\hline $\mathrm{X} 1.1$ & 0,432 \\
\hline $\mathrm{X} 1.2$ & 0,574 \\
\hline X1.3 & 0,461 \\
\hline X1.4 & 0,598 \\
\hline $\mathrm{X} 1.5$ & 0,333 \\
\hline X1.6 & 0,464 \\
\hline X1.7 & 0,598 \\
\hline $\mathrm{X} 1.8$ & 0,769 \\
\hline $\mathrm{X} 2.1$ & 0,516 \\
\hline $\mathrm{X} 2.2$ & 0,612 \\
\hline $\mathrm{X} 2.3$ & 0,661 \\
\hline X2.4 & 0,592 \\
\hline $\mathrm{X} 2.5$ & 0,663 \\
\hline X2.6 & 0,625 \\
\hline Y1 & 0,653 \\
\hline Y2 & 0,583 \\
\hline Y3 & 0,467 \\
\hline
\end{tabular}




\begin{tabular}{ll}
\hline Y4 & 0,726 \\
\hline Y5 & 0,718 \\
\hline Y6 & 0,701 \\
\hline
\end{tabular}

Sumber: diolah peneliti, 2019

Semua instrumen dalam penelitian ini, memiliki r-hitung yang lebih besar dari r-tabel pada tingkat signifikansi 0,05 sehingga valid digunakan analisis lebih lanjut.

Tabel 3. Uji Reliabilitas

\begin{tabular}{cc}
\hline Variabel & Cronbach Alpha \\
\hline $\mathrm{X} 1$ & 0,719 \\
\hline $\mathrm{X} 2$ & 0,744 \\
\hline $\mathrm{Y}$ & 0,755 \\
\hline
\end{tabular}

Sumber: diolah peneliti, 2019

Semua item pernyataan yang digunakan dalam penelitian ini memiliki koefisien keandalan (cronbach alpha) lebih besar dari 0,6 sehingga reliabel untuk dilakukan uji yang selanjutnya (Arikunto, 2006).

Tabel 4. Hasil Regresi Linier Berganda

\begin{tabular}{ccccc}
\hline Variabel & Koef. Regresi & Standar Error & t-hitung & Nilai Sig. \\
\hline Konstanta & 6.062 & 4,102 & 1,478 & 0,143 \\
\hline X1 & 0,302 & 0,133 & 2,277 & 0,026 \\
\hline X2 & 0,361 & 0,127 & 2,848 & 0,006 \\
\hline
\end{tabular}

Sumber: diolah peneliti, 2019

Model regresi linier berganda pada penelitian ini adalah $\mathrm{Y}=6.062+0.302$ $\mathrm{X}_{1}+0.362 \mathrm{X}_{2}+\mathrm{e}$, sedangkan untuk pengujian hipotesis, jika melihat nilai t-hitung untuk masing-masing variabel yaitu 2,277 > 1,989 untuk X1 dan 2,848>1,989 untuk X2 dengan nilai sig. yaitu $0,026<0,05$ dan $0,006<0,05$ maka semua variabel $\mathrm{X}$ pada penelitian ini terbukti berpengaruh positif dan signifikan terhadap variabel Y.

Model pada penelitian ini juga dilakukan uji menggunakan koefisien determinan dan Uji f untuk menilai goodness of fit model yang dapat dilihat pada Gambar 1. Untuk koefisien determinan pada penelitian ini memiliki nilai sebesar 0,221, dimana adjusted $r$ square adalah 0,201. Hal ini bermakna bahwa model penelitian ini mampu menjelaskan sebanyak $20 \%$ variabel Y. Untuk Uji f, nilai fhitung adalah $11,040>3,11$, sehingga model penelitian dapat dikatakan telah 
signifikan jika digunakan untuk pengambilan keputusan dengan kemampuan menyelesaikan masalah sebesar $20 \%$ tentang permasalahan kinerja yang mengacu pada motivasi kerja dan kompensasi di PT. JNE Cabang Kota Malang.

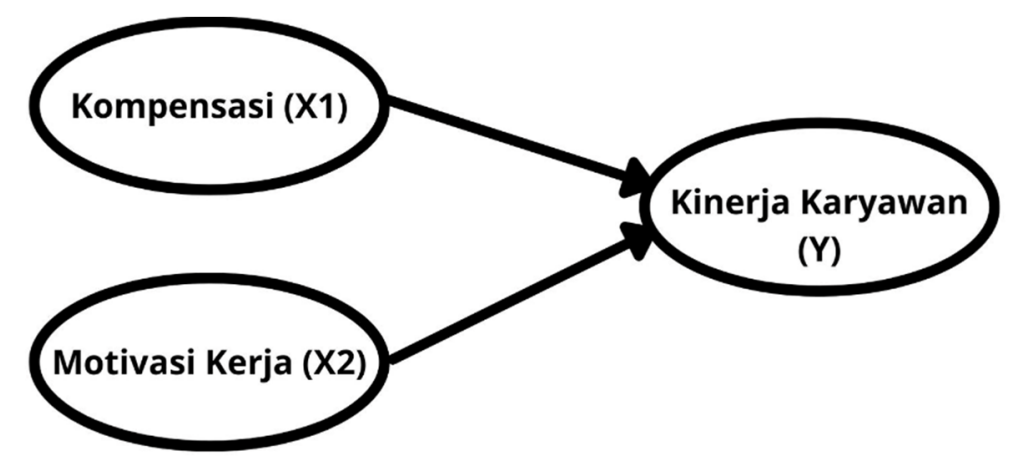

Gambar 1. Model Penelitian (diolah peneliti, 2021)

Responden pada penelitian ini didominasi oleh Pria pada divisi operational inbound dengan masa kerja 2-4 tahun. Untuk identitas responden, dapat dilihat pada Tabel 5. Sedangkan distribusi jawaban responden dapat dilihat pada Tabel 6.

Tabel 5. Identitas Responden

\begin{tabular}{ll}
\hline Jenis Kelamin & Pria $(83 \%)$ \& Perempuan $(17 \%)$ \\
\hline Divisi & Operasional Inbound $(50 \%)$ \\
& Operational Outbond $(21 \%)$ \\
& Customer Care $(10 \%)$ \\
& Sales \& Marketing $(6 \%)$ \\
& Finance \& ACC (4\%) \\
& HRD \& Admin $(9 \%)$ \\
\hline Masa Kerja & 2-4 Tahun $(59 \%)$ \\
& 5-7 Tahun $(32 \%)$ \\
& 8-10 Tahun (9\%)
\end{tabular}

Sumber: diolah peneliti, 2019 
Tabel 6. Distribusi Jawaban Responden

\begin{tabular}{|c|c|c|c|c|c|}
\hline Item & Skor & & & & \\
\hline & 1 & 2 & 3 & 4 & 5 \\
\hline X1.1 & $0 \%$ & $0 \%$ & $27 \%$ & $73 \%$ & $0 \%$ \\
\hline X1.2 & $0 \%$ & $1 \%$ & $4 \%$ & $65 \%$ & $29 \%$ \\
\hline $\mathrm{X} 1.3$ & $0 \%$ & $0 \%$ & $9 \%$ & $79 \%$ & $12 \%$ \\
\hline X1.4 & $0 \%$ & $0 \%$ & $4 \%$ & $82 \%$ & $14 \%$ \\
\hline $\mathrm{X} 1.5$ & $0 \%$ & $1 \%$ & $7 \%$ & $84 \%$ & $8 \%$ \\
\hline X1.6 & $0 \%$ & $0 \%$ & $4 \%$ & $87 \%$ & $9 \%$ \\
\hline X1.7 & $0 \%$ & $0 \%$ & $20 \%$ & $74 \%$ & $6 \%$ \\
\hline $\mathrm{X} 1.8$ & $0 \%$ & $0 \%$ & $22 \%$ & $71 \%$ & $6 \%$ \\
\hline $\mathrm{X} 2.1$ & $0 \%$ & $0 \%$ & $21 \%$ & $73 \%$ & $6 \%$ \\
\hline $\mathrm{X} 2.2$ & $0 \%$ & $1 \%$ & $26 \%$ & $61 \%$ & $12 \%$ \\
\hline $\mathrm{X} 2.3$ & $0 \%$ & $0 \%$ & $14 \%$ & $63 \%$ & $23 \%$ \\
\hline $\mathrm{X} 2.4$ & $0 \%$ & $3 \%$ & $2 \%$ & $63 \%$ & $32 \%$ \\
\hline $\mathrm{X} 2.5$ & $0 \%$ & $0 \%$ & $15 \%$ & $74 \%$ & $11 \%$ \\
\hline $\mathrm{X} 2.6$ & $0 \%$ & $0 \%$ & $9 \%$ & $74 \%$ & $17 \%$ \\
\hline $\mathrm{Y} 1$ & $0 \%$ & $0 \%$ & $2 \%$ & $62 \%$ & $36 \%$ \\
\hline $\mathrm{Y} 2$ & $0 \%$ & $0 \%$ & $7 \%$ & $69 \%$ & $24 \%$ \\
\hline $\mathrm{Y} 3$ & $0 \%$ & $1 \%$ & $5 \%$ & $65 \%$ & $29 \%$ \\
\hline Y4 & $0 \%$ & $4 \%$ & $14 \%$ & $65 \%$ & $17 \%$ \\
\hline Y5 & $0 \%$ & $1 \%$ & $12 \%$ & $73 \%$ & $14 \%$ \\
\hline Y6 & $1 \%$ & $7 \%$ & $24 \%$ & $54 \%$ & $14 \%$ \\
\hline
\end{tabular}

Sumber: diolah peneliti, 2019

Fakta dilapangan sebelumnya menunjukkan bahwa memang masih ada kecenderungan yang terjadi di PT. Jalur Nugraha Ekakurir (JNE) Cabang Kota Malang yaitu ketidakpuasan karyawan atas pemberian kompensasi berupa upah lembur yang diberikan tidak tepat waktu. Hal ini menciptakan kinerja karyawan tidak maksimal karena adanya kekecewaan dalam pemberian upah lembur yang telah diharapkan sesuai waktu tambahan pekerjaan yang telah mereka kerjakan 
(Tsai et al., 2016). Menariknya adalah penelitian ini justru menemukan fakta bahwa besaran kompensasi dan jenis tunjangan diluar gaji pokok yang diberikan PT. JNE Cabang Kota Malang sudah sesuai. Memang tidak elok jika sebuah kekecewaan karyawan hanya berasal dari upah lembur semata. Dari sini memang terbukti bahwa karyawan mampu melihat situasi dan kondisi secara komprehensif bahwa sejatinya tidak ada satupun perusahaan yang sempurna dalam menghadapi sebuah permasalahan, akan selalu ada plus dan minusnya. Lebih lanjut pula, karyawan juga mengatakan bahwa gaji yang diberikan perusahaan tidak pernah mengalami keterlambatan setiap bulan dari waktu yang telah ditentukan, dimana kompensasi utama yaitu gaji pokok sudah menjadi prioritas utama sehingga hak dan kewajiban dari karyawan sudah diberikan oleh perusahaan karena memang perusahaan logistik seperti PT. JNE Cabang Kota Malang menjadikan semua karyawan sebagai human capital tidak hanya sekedar human resource karena berperan penting dalam memberikan sumbangsih terhadap kinerja organisasi secara keseluruhan. Lebih detail tentang kompensasi dalam bentuk gaji pokok, PT. JNE Cabang Kota Malang memberikan nilai nominal yang sudah sesuai dengan peraturan pemerintah yakni sesuai dengan UMR Kota Malang yang juga diikuti dengan BPJS Kesehatan dan Ketenagakerjaan. Walaupun demikian, tidak bisa dipungkiri dalam sebuah organisasi manapun akan terjadi perbedaan kompensasi berdasarkan deskripsi pekerjaan dan tingkat kesulitan pekerjaan yang dilakukan sehingga kompensasi tersebut harus dilakukan penyesuaian. Penyesuaian ini akan mengacu kepada beberapa hal diantaranya adalah masa kerja, jabatan, deskripsi pekerjaan serta Rencana Kinerja Karyawan (RKK), dengan outcome adalah kenaikan gaji secara berkala setiap tahun.

Keterlambatan upah lembur memang dapat mengakibatkan kekecewaan karyawan, akan tetapi bisa segera diaasi dengan cara memberikan motivasi kerja kepada karyawan oleh pemimpin (Rajhans, 2012; sai et al., 2016; Olusadum \& Anulika, 2018). Seperti halnya yang sudah dilakukan oleh Branch Manager di PT. JNE Cabang Kota Malang yang tidak segan-segan untuk turun langsung ke lapangan dalam memberikan semangat setiap hari kepada para karyawannya, mendengarkan dan memberikan masukan atau jalan keluar untuk kesulitan yang dialami karyawannya dalam pekerjaan. Banyak cara yang dilakukan perusahaan untuk lebih mengenal para karyawannya seperti adanya kegiatan outbound, gathering, dan lain-lain. Hal ini kemudian mengindikasikan bahwa karyawan puas dengan motivasi yang diberikan oleh perusahaan terutama oleh atasan, serta secara otomatis akan menciptakan lingkungan kerja yang baik pula bagi perusahaan, memberikan kenyamanan karyawan dalam bekerja, sehingga karyawan dapat bekerja dengan tenang, nyaman dan senang dengan hasil kerja yang maksimal. Lebih detail tentang keberhasilan motivasi oleh Branch Manager di PT. JNE Cabang Kota Malang yaitu kebutuhan selama bekerja sudah terpenuhi dengan cukup karena keselamatan kerja karyawan terlindungi dengan baik dengan adanya kelengkapan peralatan kerja yang sesuai, dimana hal ini menunjukkan bahwa basic needs dari karyawan PT. JNE Cabang Kota Malang dijadikan prioritas sebagai hasil dari penerapan Human Capital dan tidak sekedar Human Resource. Karyawan juga merasa tidak terancam PHK karena motivational speech yang dilakukan oleh Branch Manager secara rutin telah membantu karyawan menghadapi masa sulit ketika bekerja. Lebih lanjut PT. JNE Cabang Kota Malang juga sangat terbuka bagi karyawan untuk memiliki jenjang karir yang lebih baik, namun dengan mengacu 
kepada beberapa syarat diantaranya adalah kemampuan dan keahlian yang dimiliki disesuaikan dengan deskripsi pekerjaan yang dilaksanakan, dimana semua itu akan tercantum dalam Rencana Kerja Karyawan (RKK).

Dalam sebuah organisasi atau perusahaan manapun tidak terkecuali PT. JNE Cabang Kota Malang, kompensasi dan motivasi berperan sangat penting dalam meningkatkan kinerja karyawan (Rajhans, 2012; sai et al., 2016; Olusadum \& Anulika, 2018). Bagi perusahaan logistik seperti PT. JNE Cabang Kota Malang, kompensasi memang menjadi pendorong karyawan bekerja guna mendapatkan hasil yang terbaik, dimana kompensasi yang dapat bisa memotivasi kerja karyawan, alhasil kedua hal ini perlu dibangkitkan agar karyawan dapat memberikan hasil kerjanya yang terbaik, sebaliknya karyawan yang tidak mempunyai motivasi akan sulit untuk bekerja dengan baik dan cenderung tidak bertanggung jawab sekalipun karyawan tersebut memiliki kemampuan operasional yang baik (William, 2010; Rajhans, 2012; sai et al., 2016; Olusadum \& Anulika, 2018). Apabila motivasi kerja dari para karyawan bisa dibangun, maka mereka dapat memiliki kinerja yang lebih baik di dalam organisasi atau perusahaan. Fakta dilapangan menunjukkan bahwa seluruh pekerjaan sudah dikerjakan dengan penuh tanggung jawab oleh karyawan, terutama dengan memperhatikan RKK yang dimiliki oleh mereka sudah sesuai dengan outcome yang dicapai. Keberhasilan pekerjaan ini tidak hanya perbaikan sistem yang diterapkan oleh perusahaan, namun juga adanya kesesuaian kebutuhan antara karyawan dan perusahaan sehingga tercipta kombinasi yang baik bagi kinerja perusahaan secara keseluruhan.

Penelitian ini jika dibandingkan dengan penelitian sebelumnya fokus pada kinerja karyawan pada PT. JNE Cabang Kota Malang, dimana peneliti fokus pada kompensasi dan motivasi kerja. Empiris sebelumnya lebih banyak fokus pada bidang pemasaran, sebut saja Nisa' et al., serta Attamimi et al., tahun 2020, Mutmainah tahun 2017 yang fokus pada karakteristik individu (Mutmainah, 2017; Nisa' et al., 2020; Attamimi et al., 2020). Empiris sebelumnya lebih banyak membahas tentang sisi eksternal, padahal outcome sebuah kinerja perusahaan selalu bersumber dari sisi internal. Penelitian ini juga bermaksud mengisi gap penelitian tentang kinerja yang sebelumnya dibahas oleh Mutmainah pada tahun 2017 tentang karakteristik individu, dimana penelitian ini menambahkan dua variabel yakni kompensasi dan motivasi kerja yaitu jika mengacu pada penelitian Agustin dan Sumantri pada Tahun 2017 yakni penentuan rute pengiriman di penyelenggara jasa logistik (LSP) dengan meninjau kinerja jalan di Kota Malang, telah terjadi kelebihan beban terhadap jumlah kendaraan yang melintasi jalur-jalur yang digunakan oleh perusahaan yang bergerak dibidang jasa logistik, sehingga pengiriman barang berpotensi mengalami keterlambatan (Agustin \& Sumantri, 2017). Melihat ketatnya persaingan dalam bidang jasa pengiriman barang di Indonesia terutama di Kota Malang sekarang ini, penelitian terhadap kinerja karyawan pada perusahaan logistik seperti PT. JNE Cabang Kota Malang menjadi menarik karena adanya pengaruh dari kompensasi dan motivasi kerja di perusahaan tersebut akan berpengaruh terhadap kinerja perusahaan secara keseluruhan nantinya (Agustin \& Sumantri, 2017; Nugroho et al., 2020). Secara sederhana, peneliti sebelumnya menjelaskan bahwa dengan tersedianya beberapa penyedia layanan logistik di Kota Malang, maka rute pengiriman perlu untuk diperhatikan sehingga tidak terjadi penumpukan dijalan, selain itu juga dapat mempercepat waktu perjalanan barang sampai tepat waktu kepada konsumen karena ketika konsumen 
mendapatkan barang secara tepat waktu, maka ia akan puas dan secara jangka panjang akan bertahan untuk tetap menggunakan jasa dari JNE. Beberapa penelitian ini fokus pada rute pengiriman dan pelanggan atau konsumen, dimana terdapat satu hal yang terlupa yakni fokus pada karyawan yang bertindak sebagai pemain utama dalam rangka memastikan barang dapat diterima dengan baik oleh konsumen sehingga kepuasan konsumen tetap terjaga. Dari sisi jumlah responden, penelitian ini juga lebih baik dari penelitian sebelumnya karena menggunakan teknik proportional sampling dimana semua divisi yang ada pada PT. JNE Cabang Kota Malang ikut dianalisis sehingga penelitian ini mampu menunjukkan hasil yang lebih baik dan menyeluruh dibandingkan empiris sebelumnya. Penelitian ini juga memiliki kemampuan memprediksi yang lebih baik terhadap kinerja karyawan PT. JNE Cabang Kota Malang sehingga bisa dijadikan sebagai rujukan dalam pengambilan keputusan terutama di masa pandemi saat ini dimana perusahaan logistik memainkan peran penting dalam aktivitas transaksi ekonomi.

Secara empiris, penelitian ini mendukung beberapa hasil penelitian sebelumnya yakni kompensasi memang mampu meningkatkan kinerja karyawan, terutama di perusahaan yang bergerak di bidang jasa (Rajhans, 2012; sai et al., 2016; Olusadum \& Anulika, 2018), serta motivasi kerja karyawan memang perlu dibangkitkan agar karyawan dapat memberikan hasil kerjanya yang terbaik, sebaliknya karyawan yang tidak mempunyai motivasi atau semangat yang tinggi dalam melakukan pekerjaannya akan sulit untuk bekerja dengan baik dan cenderung tidak bertanggung jawab sekalipun karyawan tersebut memiliki kemampuan operasional yang baik (William, 2010; Rajhans, 2012; sai et al., 2016; Olusadum \& Anulika, 2018).

\section{Simpulan}

Penelitian ini berhasil menyatakan bahwa kompensasi dan motivasi kerja berpengaruh signifikan terhadap kinerja karyawan di PT. JNE Cabang Kota Malang. Bagi perusahaan, penelitian ini bisa digunakan sebagai rujukan untuk pengambilan keputusan dimana kinerja karyawan bisa ditingkatkan jika diikuti dengan peningkatan kompensasi. Selain itu, memotivasi kerja karyawan perlu menjadi prioritas dibandingkan dengan kompensasi untuk PT. JNE Cabang Kota Malang. Hal ini karena karyawan membutuhkan komunikasi yang baik terlebih dahulu agar terbangun suasana dan kondisi kerja yang baik, sehingga kompensasi yang diterima bisa segera berubah menjadi outcome yang diharapkan perusahaan. Setiap penelitian tentu memiliki keterbatasan, tidak terkecuali dalam penelitian ini. Keterbatasan dalam penelitian ini adalah ketika melakukan pengambilan sampel, peneliti menemukan responden kesulitan untuk fokus mengisi kuesioner karena padatnya jam kerja mereka, terutama mereka yang berada pada bagian operational inbound dan operational outbound, sehingga bagi peneliti selanjutnya bisa mempertimbangkan waktu pengambilan sampel bagi dua bagian ini untuk diberikan waktu yang lebih fleksibel karena padatnya jam kerja. Sebagai tambahan, bagi peneliti selanjutnya yang ingin meneliti PT. JNE Cabang Kota Malang bisa menambahkan variabel komunikasi interpersonal, locus of control dan innovative work behavior karena kemampuan individu sebagai human capital di perusahaan jasa sangat menentukan kinerja perusahaan secara keseluruhan. 


\section{Daftar Pustaka}

Agustin, I. W., \& Sumantri, Y. (2017). Determination of Route Delivery in the Logistic Service Provider (LSP) by Reviewing the Performance of Street in The City of Malang. IOP Conference Series: Materials Science and Engineering, 180, 012140. https://doi.org/10.1088/1757-899X/180/1/012140

Anthonia. N, O., Okeke, M. N., \& Ikechukwu, I. A. (2019). Compensation Management and Employee Performance in Nigeria. International Journal of Academic Research in Business and Social Sciences, 9(2), Pages 384-398. https://doi.org/10.6007/IJARBSS/v9-i2/5552

Attamimi, F. M., Hufron, M., \& Rahman, F. (n.d.). Pengaruh Kualitas Pelayanan, Harga, Dan Ketepatan Waktu Terhadap Kepuasan Konsumen (Studi Pada Konsumen JNE Kota Malang). 13.

Baker, G. P., Jensen, M. C., \& Murphy, K. J. (1988). Compensation and Incentives: Practice vs. Theory. The Journal of Finance, 43(3), 593-616. https://doi.org/10.1111/j.1540-6261.1988.tb04593.x

Bangun, W. (2012). Manajemen Sumber Daya Manusia, Erlangga. Erlangga.

Bao, C., \& Nizam, I. (2015). The Impact Of Motivation On Employee Performance In The Electronics Industry In China. International Journal of Accounting and Business Management, 3(2), 29-45. https://doi.org/10.24924/ijabm/2015.11/v3.iss2/29.45

Decramer, A., Smolders, C., \& Vanderstraeten, A. (2013). Employee performance management culture and system features in higher education: Relationship with employee performance management satisfaction. The International Journal of Human Resource Management, 24(2), 352-371. https://doi.org/10.1080/09585192.2012.680602

Gofur, A. (2019). Pengaruh Kualitas Pelayanan Dan Harga Terhadap Kepuasan Pelanggan. Jurnal Riset Manajemen dan Bisnis (JRMB) Fakultas Ekonomi UNIAT, 4(1), 37-44. https://doi.org/10.36226/jrmb.v4i1.240

Hasibuan, M. S., \& Hasibuan, H. M. S. (2016). Manajemen sumber daya manusia. Bumi Aksara.

Juvendy, B., \& Hendriati, Y. (2020). Analisis Pengaruh Reward, Motivasi, Dan Kepuasan Kerja Terhadap Turnover Intention Pada Pt. Indo Niniki. 4, 9.

Kasmir, K. (2016). Manajemen Sumber Daya Manusia. PT Raja Grafindo Persada.

Ketkaew, C., Manglakakeeree, O., \& Naruetharadhol, P. (2020). The interrelationships of work-related factors, person-environment fit, and employee turnover intention. Cogent Business \& Management, 7(1), 1823580. https://doi.org/10.1080/23311975.2020.1823580

Muthusi Nzyoka, C. (2016). The Relationship Between Total Compensation and Employee Performance in the Insurance Industry, Case of Mayfair Insurance Company Limited. Psychology and Behavioral Sciences, 5(1), 20. https://doi.org/10.11648/j.pbs.20160501.14

Mutmainah, M. (2017). Peran Karakteristik Individu Pada Peningkatan Kinerja Karyawan (Studi pada PT. TIKI JNE (Jalur Nugraha Ekakurir) Cabang Malang). Jurnal Ekomaks, 3(1).

Nugroho, S., Kempa, S., \& Wiliater Soaloon Panjaitan, T. (2020). Logistic Service Quality and Customer Satisfaction to Customer Retention on Rice Producer 
Industry. SHS Web of Conferences, 76, 01048. https://doi.org/10.1051/shsconf/20207601048

Olusadum, N. J., \& Anulika, N. J. (2018). Impact of Motivation on Employee Performance: A Study of Alvan Ikoku Federal College of Education. Journal of Management and Strategy, 9(1), 53. https://doi.org/10.5430/jms.v9n1p53

Rajhans, K. (2009). Effective Organizational Communication: A Key to Employee Motivation and Performance. Interscience Management Review, 145-149. https://doi.org/10.47893/IMR.2009.1040

Robbins, S. P. (2008). Perilaku Organisasi (10th ed.). Salemba Empat.

Rodwell, J. J., Kienzle, R., \& Shadur, M. A. (n.d.). The Relationships Among Workrelated Percep- Tions, Employee Attitudes, And Employee Perfor-Mance: The Integral Role Of Communication. 17.

Sedarmayanti, S. (2011). Tata Kerja dan Produktivitas Kerja. Mandar Maju.

Suharsimi, A. (2006). Prosedur penelitian suatu pendekatan praktik. Jakarta: Rineka Cipta, 120-123.

Sutrisno, E. (2013). Manajemen sumber daya manusia. Kencana Prenada Media Group.

Tsai, M.-C., Nitta, M., Kim, S.-W., \& Wang, W. (2016). Working Overtime in East Asia: Convergence or Divergence? Journal of Contemporary Asia, 46(4), 700-722. https://doi.org/10.1080/00472336.2016.1144778

Wiliam, A. N. (2010). Employee Motivation and Performance. Mikkeli University of Applied Sciences.

Wong, K., Chan, A. H. S., \& Ngan, S. C. (2019). The Effect of Long Working Hours and Overtime on Occupational Health: A Meta-Analysis of Evidence from 1998 to 2018. International Journal of Environmental Research and Public Health, 16(12), 2102. https://doi.org/10.3390/ijerph16122102 